\title{
Growth performance and sensory parameters of African catfish (Clarias gariepinus) fed with a sublethal dose of neem leaf extract, and its antibacterial effects
}

\author{
Oniovosa E. Ubiogoro, Selim A. Alarape*, Akeem B. Saka, \\ and Olanike K. Adeyemo \\ Department of Veterinary Public Health and Preventive Medicine, Faculty of Veterinary Medicine, \\ University of Ibadan, Ibadan, Nigeria
}

UBIOGORO, O. E., S. A. ALARAPE, A. B. SAKA, O. K. ADEYEMO: Growth performance and sensory parameters of African catfish (Clarias gariepinus) fed with a sublethal dose of neem leaf extract, and its antibacterial effects. Vet. arhiv 89, 709$721,2019$.

\section{ABSTRACT}

The antibacterial effects of Neem leaf, the growth performance and sensory qualities of African catfish fed with Neem leaf inclusion were investigated in this study. Ninety (90) post-juvenile Clarias gariepinus (42.40 $\pm 2.50 \mathrm{~g}$ ) were used. Experimental groups in triplicate were exposed bi-weekly to $3.5 \%$ and $7 \% \mathrm{LC}_{50}$ of Neem leaves aqueous extract infused in commercial floating feed for four weeks, while the control group was exposed to untreated feed. The whole body length and weight of randomly sampled fish were taken for organo-somatic indices. Gills and skin samples were collected for bacteriological screening, while fish muscles were prepared for sensory acceptability tests. Mean feed intake was significantly $(\mathrm{P}<0.05)$ influenced by Neem leaf in the three treatment concentrations with an insignificant difference between the treated groups, but it was higher than in the control group. Mean weight gain was significantly higher $(\mathrm{P}<0.05)$ in the Neem fed fish than the control but insignificant the differences between treatment doses were insignificant, while the feed conversion ratio was significantly lower $(\mathrm{P}<0.05)$ in the Neem fed groups compared to the control, but the difference was insignificant between the treatment doses. All groups were apparently healthy looking with $100 \%$ survival. There was a considerable reduction in total bacterial count in both the gills and skin with the increase in Neem concentration. Micrococci spp. and Bacillus subtilis were not isolated in the gills but were present in the skin, while $E$. coli and Pseudomonas fluorescens were not suppressed in the skin. There was no significant difference $(\mathrm{P}<0.05)$ in all the sensory parameters across all groups. The inclusion of Neem leaf extract was shown to have a high antibacterial effect coupled with excellent growth performance and general acceptability of fish tissue.

Key words: aquaculture; Neem; antibacterial; growth; Clarias gariepinus

\footnotetext{
*Corresponding author:

Dr Selim Adewale Alarape (DVM, MVPH), Department of Veterinary Public Health and Preventive Medicine, Faculty of Veterinary Medicine, University of Ibadan, Ibadan, Nigeria, Phone: +234 0805350 6599; E-mail: link2sas@yahoo.co.uk
} 
O. E. Ubiogoro et al.: Growth performance and sensory parameters of African catfish (Clarias gariepinus) fed with sublethal dose of neem leaf extracts and its antibacterial effects

\section{Introduction}

Aquaculture is one of the fastest growing food production sectors in the world, with global inland aquaculture production increased from 29.9 million tonnes in 2007 to 41.9 million tonnes in 2012 (FAO, 2014). Nigeria has not been left out of this trend as it provides a suitable and cheap substitute for dietary protein. With this production surge, aquaculture facilities are increasingly relying on the heavy input of formulated feeds, antibiotics, antifungal products, and agrochemicals for increased production. The intensive use of antibiotics, growth boosters and chemicals has raised questions about the impact of veterinary medicines on livestock production, the environment and on human health.

The Neem plant (Azadirachta indica) is a non-leguminous multi-purpose tree which belongs to the family Meliceae, otherwise known as Nim tree and Margosa tree (ARBONNIER, 2004). It is a common, thriving, fast growing, evergreen and readily available plant in Nigeria, believed to be native to the Indian subcontinent (GIRISH and SHANKARA, 2008) and Senegal (ORWA et al., 2009). It has been reported to boost the immune system of humans, and several animals and fish species (MUKESH et al., 2012; KWAWUKUME et al., 2013; SHAILENDER et al., 2013). HARIKRISHNAN et al., 2003, also reported that the Neem plant has antibacterial, antifungal, antiviral and pesticidal activities, while at the same time improving general growth and health performance, with no toxic effect to vital organs.

Neem, despite its bitter taste, has been introduced and investigated in the composition of livestock diet as Neem Seed Cake, due to the presence of essential amino acids, crude protein, fibre, Sulphur and Nitrogen (ESONU et al., 2005; ESONU et al., 2006; OFORJINDU, 2006; UKO and KAMALU, 2007; OGBUEWU, 2008) and Neem Leaf Meal (UKO and KAMALU, 2001; BAROA et al., 2006; ODUNSI et al., 2009; ARUWAYO and MAIGANDI, 2013), as a replacement for groundnut or soya beans due to its high protein component without any adverse effects. NNENNA and ANIEBO (2013) in their work on broiler chicks demonstrated the potentials of Neem leaf extracts as a source of nutrients needed by animals. Their report presented the comparable weight gain of the birds fed Neem leaf extract to the control, indicating that the quantity of toxic factors such as terpenes and limonoids (OGBUEWU et al., 2011; KABEH and JALINGO, 2007) in the Neem leaf was minimal and did not impair its nutrient availability, digestion, absorption and utilization.

Several researchers have investigated feed consumption and weight gain activity of Neem in animals. GOWDA and SASTRY, (2000) and UKO and KAMALU, 2008 suggested that raw Neem toxicity and the presence of bitter compounds impair feed intake, while experimental removal of the bitter toxicant - triterpenoids from Neem cake with alkali and caustic soda increased Neem feeding value and protein utilization, with 
O. E. Ubiogoro et al.: Growth performance and sensory parameters of African catfish (Clarias gariepinus) fed with sublethal dose of neem leaf extracts and its antibacterial effects

impressive growth in poultry birds (NAGALAKSHMI et al., 1996; OGBUEWU et al., 2011). Studies on Neem in animal production have been mostly focused on its medicinal uses, mostly as an anthelminthics agent (CHANDRAWATHANI et al., 2006; TIWARY and PANDEY, 2010), while most studies in the area of animal nutrition have involved the use of the seeds as a protein source in animal feed (GOWDA and SASTRY, 2000; OGBUEWU et al., 2011).

Neem leaves are high in crude protein, though with wide variations in the reported values, which may be due to varietal differences in the plant. BAIS et al., 2002 and BHOWMIK et al., 2008 reported crude protein concentrations between $17.5 \%$ and 18.7\%, 9.7\% (RAMANA et al., 2000) and 20.9\% (OGBUEWU et al., 2011). According to RAMANA et al., 2000, Neem leaves contain 38.0\% Neutral Detergent Fibre (NDF) and $27.0 \%$ Acid Detergent Fibre (ADF) levels while BHOWMIK et al., (2008) reported $11.3 \%$. Its calcium content ranges between $1.48 \%$ and $1.53 \%$, which is related to the calcium content $(1.51 \%)$ available in Sesbania leaves, reported by NGAMSAENG et al., 2006. Neem leaves have been reported to be deficient in copper and manganese (NIRANJAN et al., 2008), zinc and phosphorus (RAO et al., 2011). PAENGKOUM (2010) reported that Neem leaves can replace up to $50 \%$ of soya bean meal in ruminant diets with no negative effects on feed intake, dry matter and fibre digestibility, as well as body weight gain. CHANDRAWATHANI et al., 2006 and TIWARY and PANDEY, 2010, revealed that there are also many scientific reports on the anthelminthic properties of Neem leaves and extracts in ruminants, which include Haemonchus contortus sensitivity in fed animals. Improved performance with Neem leaves has also been reported for poultry (SONAIYA, 1993). This study was therefore aimed at ascertaining the antibacterial and growth promoting properties of Neem leaf extract in cultured fish feed.

\section{Materials and methods}

Sample source and aqueous neem leaf preparation. A total of ninety (90), ten-weekold African Catfish (Clarias gariepinus) (post juveniles) (42.40 $\pm 2.50 \mathrm{~g})$ were acquired. They were acclimatized and subsequently transferred to experimental fibre plastic tanks, as described by ONIOVOSA et al., 2017. The juveniles were stocked at a density of 10 fish per 50 litre water tank. An aqueous extraction of Neem leaves was prepared according to the method described by CROSS et al. (2004) while incorporation of the aqueous extract into the fish feed at $3.5 \%$ and $7 \%$ concentrations, and the experimental set up were done as described by ONIOVOSA et al., 2017.

Fish were randomly sampled from each experimental group at the start of the experiment with measurement of their weight and length. At the end of the experiment, the length and whole body weight of randomly sampled fish, as well as the weight of the various organs were recorded for organo-somatic indices. Gill and skin samples 
O. E. Ubiogoro et al.: Growth performance and sensory parameters of African catfish (Clarias gariepinus) fed with sublethal dose of neem leaf extracts and its antibacterial effects

were collected for bacteriological screening, while other fish samples were prepared for sensory acceptability tests.

Fish samples for sensory acceptability test were washed with clean water, properly labelled and stored on ice in an insulated flask for transfer to the kitchen. They were de-gutted, cut into uniform sizes, washed with clean water and steamed separately with a pinch of iodized salt in $30 \mathrm{cL}$ of clean water for 10 minutes and allowed to cool to a reasonable serving temperature. A similar part of each fish was presented for evaluation to each member of the panel (Five (5) semi-trained persons from the university community) in coded digital labels to conceal every information about the samples, in order to avoid bias in judgement. After each sample, mouth rinsing with clean water and a waiting time of about 5 minutes was encouraged for clarity of taste. Palatability and acceptability was subjected to the Quality Index Method (QIM) of sensory quality evaluation.

The sensory parameters were scored by the analysts using the following parameters: Appearance/ coloration (Fish white, dull white, slightly yellowish, yellowish discolouration); Taste /flavour (Sweet, off flavor, slightly bitter, very bitter); Odour (Fresh, neutral, offensive); Overall acceptability (highly acceptable, acceptable, fairly acceptable, not acceptable).

Growth rate evaluation. At the end of the experiment, the Initial Mean Weight (IMW), Final Mean Weight (FMW), Mean Weight Gain (MWG), Percentage Weight Gain (PWG), Mean Feed Intake (MFI), Feed Conversion Rate (FCR) and Survival Rate were calculated and analysed statistically using SPSS, (1999).

Mean Weight Gain $(\mathrm{MWG})=\mathrm{Wf}-\mathrm{Wi}$

where

Wi means Initial weight $(\mathrm{g})$ and Wf means Final weight $(\mathrm{g})$

Feed Conversion Ratio $(\mathrm{FCR})=$ Mass of food consumed dry $\times 100$

Increase in mass of animal produced wet $=($ Total dry feed fed $) /($ Wet weight gain $)$

Survival rate $(\mathrm{SR})=\frac{\text { Initial number of fish stocked }- \text { mortality }}{\text { Initial number of fish }} \times 100$ 
O. E. Ubiogoro et al.: Growth performance and sensory parameters of African catfish (Clarias gariepinus) fed with sublethal dose of neem leaf extracts and its antibacterial effects

Table 1. Sensory palatability score form for cooked fish

\begin{tabular}{|l|c|c|}
\hline \multirow{4}{*}{ Quality parameter } & Score guide & Score \\
\hline \multirow{4}{*}{ Appearance/ coloration } & White & 4 \\
\cline { 2 - 3 } & Dull & 3 \\
\cline { 2 - 3 } Taste /flavor & Light yellow & 2 \\
\cline { 2 - 3 } & Deep yellow & 1 \\
\hline \multirow{4}{*}{ Odor } & Sweet & 4 \\
\cline { 2 - 3 } & Off flavor & 3 \\
\hline & Slightly bitter, & 2 \\
\hline \multirow{4}{*}{ Overall acceptability } & Very bitter & 1 \\
\cline { 2 - 3 } & Fresh (sea weed) & 3 \\
\cline { 2 - 3 } & Neutral (odor-less) & 1 \\
\hline Score total & Offensive & 4 \\
\cline { 2 - 3 } & Highly acceptable & 3 \\
\cline { 2 - 3 } & Acceptable & 2 \\
\cline { 2 - 3 } & Fairly acceptable & 1 \\
\hline
\end{tabular}

Total scores were analyzed for significant difference

Statistical analysis. The values obtained were expressed as mean \pm SEM (standard error of mean). The homogeneity of data was analyzed by one-way analysis of variance (ANOVA) and the Bonferroni's Multiple Comparison Test was used as test for comparison between means using Graph-Pad Prism (version 4.00 for Windows, Graph-Pad Software, San Diego, California, USA). The significances of the P values $<0.05$ were also considered.

\section{Results}

The growth performance of the fish (Table 2) showed that mean feed intake was significantly $(\mathrm{P}<0.05)$ influenced by Neem leaf in the treatment concentrations (T2 and T3) compared with the control (T1), although there was no significant difference within the treated groups. Mean weight gain was significantly higher $(\mathrm{P}<0.05)$ in the Neem fed fish compared to the control, but the difference was not significant between the treatment doses. Similarly the feed conversion ratio was significantly lower $(\mathrm{P}<0.05)$ in the Neem fed groups compared to the control but there were no significant differences between the treatment doses. All groups were apparently healthy looking with 100\% survival. 
O. E. Ubiogoro et al.: Growth performance and sensory parameters of African catfish (Clarias gariepinus) fed with sublethal dose of neem leaf extracts and its antibacterial effects

Table 2. Effect of aqueous Neem leaf extract on fish growth parameters, feed intake, feed conversion ratio and survival rate

\begin{tabular}{|l|c|c|c|}
\hline Parameters & T1 $(0 \%)$ & T2 $(3.5 \%)$ & T3 (7\%) \\
\hline Initial Mean Weight $(\mathrm{g})$ & $39.58 \pm 2.10^{\mathrm{a}}$ & $42.45 \pm 2.54^{\mathrm{a}}$ & $40.92 \pm 1.98^{\mathrm{a}}$ \\
\hline Final Mean Weight $(\mathrm{g})$ & $67.57 \pm 2.46^{\mathrm{b}}$ & $77.64 \pm 4.44^{\mathrm{a}}$ & $76.75 \pm 4.00^{\mathrm{a}}$ \\
\hline Mean Weight Gained $(\mathrm{g})$ & $27.99 \pm 0.73^{\mathrm{b}}$ & $35.18 \pm 1.93^{\mathrm{a}}$ & $35.84 \pm 2.02^{\mathrm{a}}$ \\
\hline Percentage Weight Gain & $70.83 \pm 3.61^{\mathrm{a}}$ & $82.90 \pm 1.21^{\mathrm{b}}$ & $87.56 \pm 0.72^{\mathrm{c}}$ \\
\hline Mean Feed Intake $(\mathrm{g} /$ day) & $26.24 \pm 0.93^{\mathrm{b}}$ & $29.92 \pm 1.56^{\mathrm{a}}$ & $29.43 \pm 0.82^{\mathrm{a}}$ \\
\hline Feed Conversion Ratio & $0.94 \pm 0.01^{\mathrm{a}}$ & $0.85 \pm 0.00^{\mathrm{b}}$ & $0.82 \pm 0.03^{\mathrm{b}}$ \\
\hline Survival Rate & $100 \pm 00^{\mathrm{a}}$ & $100 \pm 0.00^{\mathrm{a}}$ & $100 \pm 0.00^{\mathrm{a}}$ \\
\hline
\end{tabular}

Means with the same superscripts are not significantly different $(\mathrm{P}<0.05)$.

Antibacteriological effects. The bacterial organisms isolated from the experimental fish samples were; Escherichia coli, Micrococci spp. Pseudomonas fluorescens, Aeromonas hydrophila, Bacillus subtilis, Bacillus megaterus, Proteus spp. and Klebsiella.

Table 3 showed the considerable reduction in total bacterial count in both the gills and skin of sampled fish with an increase in Neem concentration. Micrococci spp. and Bacillus subtilis were not isolated in the gills (Table 4) but were present in the skin (Table 5). Escherichia coli, Bacillus megaterus and Proteus spp. in the gills were resistant to the Neem leaf extract at both concentrations (Table 4), while Aeromonas hydrophila was only susceptible at the 7\% (T3) concentration in the gill. In the skin sample, E. coli and Pseudomonas fluorescens were resistant to Neem leaf extract at both concentrations, Micrococci spp. Klebsiella spp. and Bacillus megaterus were susceptible to Neem leaf extract at both concentrations while Aeromonas hydrophila, Bacillus subtilis and Proteus were only susceptible at the 7\% (T3) concentration.

Table 3. Total bacterial count $\times 10^{6} \mathrm{cfu} / \mathrm{mL}$ in the gills and skin of sampled fish at different neem concentrations

\begin{tabular}{|l|c|c|c|}
\hline Fish organ & T1 (Control) & T2 $(3.5 \%)$ & T3 (7\%) \\
\hline Gill & 5.8 & 5.2 & 4.0 \\
\hline Skin & 6.1 & 3.6 & 3.3 \\
\hline
\end{tabular}


O. E. Ubiogoro et al.: Growth performance and sensory parameters of African catfish (Clarias gariepinus) fed with sublethal dose of neem leaf extracts and its antibacterial effects

Table 4. Bacterial organisms isolated from fish gills

\begin{tabular}{|c|c|c|c|c|c|c|c|c|}
\hline Gill & $\begin{array}{l}\ddot{8} \\
\dot{0}\end{array}$ & 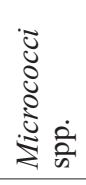 & 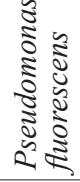 & 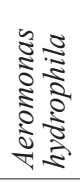 & 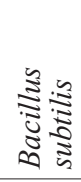 & $\begin{array}{l}\frac{1}{2} \\
0 \\
\vdots \\
0 \\
0 \\
0 \\
0\end{array}$ & 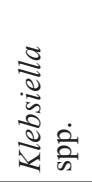 & 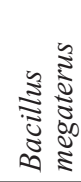 \\
\hline $\mathrm{T} 1$ & + & - & + & + & - & + & + & + \\
\hline $\mathrm{T} 2$ & + & - & - & + & - & + & - & + \\
\hline T3 & + & - & - & - & - & + & - & + \\
\hline
\end{tabular}

Table 5. Microbial organisms isolated from fish skin

\begin{tabular}{|c|c|c|c|c|c|c|c|c|}
\hline Skin & $\begin{array}{l}\tilde{8} \\
0\end{array}$ & 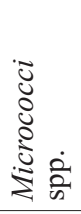 & 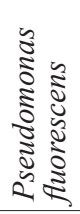 & 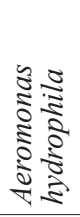 & 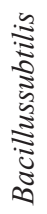 & 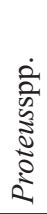 & 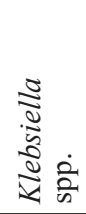 & 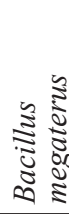 \\
\hline T1 & + & + & + & + & + & + & + & + \\
\hline $\mathrm{T} 2$ & + & - & + & + & + & + & - & - \\
\hline T3 & + & - & + & - & - & - & - & - \\
\hline
\end{tabular}

Sensory score result analysis. The sensory scores results (Fig. 1) showed no significant differences $(\mathrm{P}<0.05)$ in the color, taste, odor and general acceptability across all groups, although a slight coloration occurred at $3.5 \%$ concentration on visual observation.

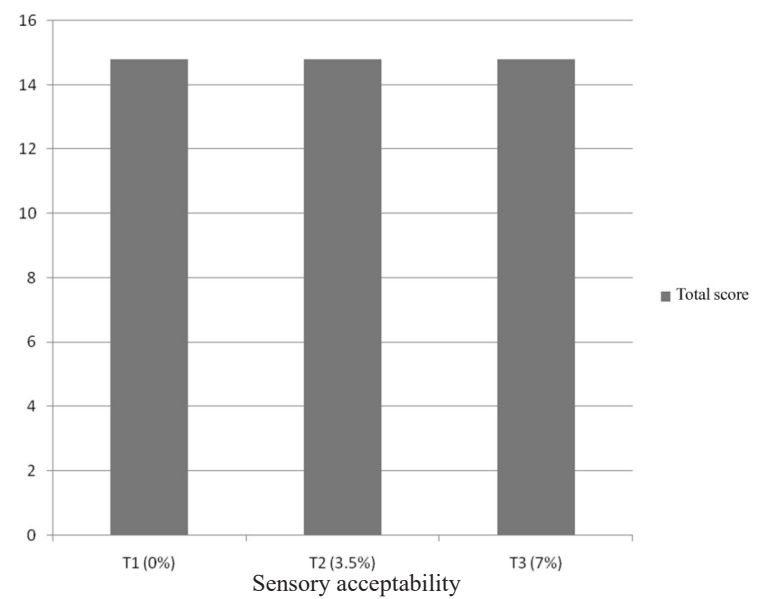

Fig. 1. Pictorial presentation of sensory scores. Sensory acceptance graded at the same level for all concentrations of Neem used in this experiment.

Vet. arhiv 89 (5), 709-721, 2019 
O. E. Ubiogoro et al.: Growth performance and sensory parameters of African catfish (Clarias gariepinus) fed with sublethal dose of neem leaf extracts and its antibacterial effects

\section{Discussion}

Growth performance. The average feed intake of fish was not affected by the bitter taste of the Neem leaf, contrary to the findings of GOWDA and SASTRY (2000), making the process of detoxifying Neem for the purpose of increased palatability and acceptance in feed, as proposed by NAGALAKSHMI et al. (1996), not necessary for catfish. This feed intake and weight gain report is in agreement with the work of OGBUEWU et al. (2011) and KABEH and JALINGO (2007) which stated that in birds, the quantity of toxic factors, such as terpenes and limonoids in Neem leaf did not impair the nutrient availability, digestion, absorption and utilization of feed. Contrary to the report of BONSU et al., (2012) on broilers fed with Neem leaf, the result obtained in this research showed the positive significant effect of Neem leaf inclusion on both weight gain and feed conversion efficiency of juveniles of Clarias gariepinus, which is in agreement with the report by TALPUR and IKHWANUDDIN (2012) for Lates calcarifer fingerlings.

Bacteriological response. The antibacterial property of Neem leaves the in gills and skin of Clarias gariepinus was shown in the decrease in the total bacteria count in response to an increase in Neem leaf treatment concentrations, which is in agreement with reports by several researchers (PEDGE and AHIRRAO, 2012; RAVIKUMAR et al., 2011; MADHURI et al., 2012). The effect of Neem on Aeromonas hydrophila in this study is in line with the work of HARIKRISHNAN et al., (2003) on carp fish, as the 7\% concentration inclusion of Neem leaf extract successfully suppressed Aeromonas hydrophila in all samples. The suppressed bacterial pathogens in this study are also in agreement with the report by DHAYANITHI et al. (2010) on ornamental marine fishes. Klebsiella, Bacillus subtilis, Micrococci spp. were successfully suppressed by the inclusion of Neem in the fish diet, similar to the report by RAM et al., (2002) on Klebsiella pneumonia, but contrary to this same author on E. coli as all experimental groups, including the $7 \%$ treatment concentration of Neem remained positive to E. coli. Pseudomonas fluorescens was also not affected at these concentrations of Neem leaf extract.

Sensory quality. Although, CLAUSEN et al., (1985) discouraged the use of products with an unpleasant taste in animal feed, saying that there is a chance that the unpleasant bitter taste of the plant might have impact on the smell and taste of the meat, the results of this research demonstrate the opposite as samples of fish fed Neem leaf in their diet presented no trace of the taste of the Neem in terms of coloration, odor or taste, even at the $7 \%$ concentration. As observed regarding the sensory acceptability of Clarias gariepinus in this present study, there was no significant difference between the treatment and the control group, which was similar to the report by BONSU et al., (2012), who recorded a mild bitter taste change in the meat of broiler chicken fed a relatively high percentage of Neem leaf, although it had positive sensory acceptability. 
O. E. Ubiogoro et al.: Growth performance and sensory parameters of African catfish (Clarias gariepinus) fed with sublethal dose of neem leaf extracts and its antibacterial effects

\section{Conclusion}

Neem plants are readily available, low in toxidity, environmentally friendly and rich in several biologically active components that give them multifunctional ability. As revealed in this experimental research, aqueous Neem leaf extract infused into catfish feed at sub-lethal concentrations has no negative effect on the sensory quality values and general acceptability of the fish muscle. Neem leaf inclusion in feed has a remarkable positive effect in the suppression of bacteria growth, as well improved general growth performance (weight gain and feed conversion efficiency). Due to the growth- promoting and antibacterial properties of Neem leaf extracts, funding of research leading towards its standardization in the management of aquatic animal diseases, as well as livestock health, should be encouraged.

\section{References}

ARBONNIER, M. (2004): Trees, Shrubs and Lianas of West African Dry Zones. Muséum National d'Histoire naturelle, Paris; Cirad, Versailles; Margraf, Weikersheim, p. 573.

ARUWAYO, A., S. A. MAIGANDI (2013): Neem (Azadirachta indica) seed cake/kernel as protein source in ruminants feed. Am. J. Exp. Agric. 482-494.

DOI: 10.5281 /zenodo.8217.

BAIS, B., G. R. PUROHIT, R. K. DHURIA, U. PANNU (2002): Nutritive value of sares and neem leaves in Marwari goats. Indian J Anim Sci. 19, 266-268.

BARAO, I., A. M. HANASH, W. HALLETT, L. A. WELNIAK, K. SUN, D. REDELMAN, B. R. BLAZAR, R. B. LEVY, W. J. MURPHY (2006): Suppression of natural killer cell-mediated bone marrow cell rejection by CD4+CD25+ regulatory T cells. Proc. Natl. Acad. Sci. 103, $5460-5465$.

DOI: $10.1073 /$ pnas.0509249103

BHOWMIK S., S. D. CHOWDHURY, M. H. KABIR, M. A. ALI (2008): Chemical composition of some medicinal plant products of indigenous origin. The Bangladesh Veterinarian, 25, 32-39. DOI: $10.3329 /$ bvet.v25i1.4616

BONSU F. R. K., J. K. KAGYA-AGYEMANG, W. K. J. KWENIN, H. K. ZANU (2012): Medicinal response of broiler chickens to diets containing neem (azadirachta indica) leaf meal, haematology and meat sensory analysis. World Appl. Sci. J. 19, 800-805.

DOI: 10.5829/idosi.wasj.2012.19.06.827

CHANDRAWATHANI P., K. W. CHANG, R. NURULAINI, P. J. WALLER, M. ADNAN, C. M. ZAINI, O. JAMNAH, S. KHADIJAH, N. VINCENT (2006): Daily feeding of fresh Neem leaves (Azadirachta indica) for worm control in sheep. Trop. Biomed. 23, 23-30.

CLAUSEN, S. L. M., A. LARSEN-PLOGER, H. SORENSEN (1985): Advances in the production and utilization of cruciferous crops. Junk publications, Netherlands. 3, 25-31. 
O. E. Ubiogoro et al.: Growth performance and sensory parameters of African catfish (Clarias gariepinus) fed with sublethal dose of neem leaf extracts and its antibacterial effects

CROSS, C., J. G. AX-NETO, M. L. MENEZES (2004): Acute toxicity of metallic insecticide and azadiractin biopesticide of neem (Azadirachta indica) leaves for jewish and pacu youth (Piaractus mesopotamicus). Pesticidas: R. Ecotoxicol. e. 14, 93-102.

DOI: 10.5380 / pes.v14i0.3127

DHAYANITHI N. B., T. T. AJITH KUMAR, K. KATHIRESAN (2010): Effect of neem extract against the bacteria isolated from marine fish. J. Environ. Biol. 31, 409-412.

ESONU B. O., O. O. EMENALOM, A. B. I. UDEDIBIE, G. A. ANYANWU, U. MADU, A. O. INYANG (2005). Evaluation of Neem (Azadirachta indica) leaf meal on performance, carcass characteristics and egg quality of laying hens. Int. J. Agric. Dev. 6, 208-212.

DOI: $10.4314 /$ ijard.v6i1.2611

ESONU, B. O., M. N. OPARA, I. C. OKOLI, H. O. OBIKAONU, C. UDEDIBIE, O. O. M. IHESHIULOR (2006): Physiological responses of laying birds to Neem (Azadirachta indica) leaf meal based diets, body weight organ characteristics and hematology. Online J. Hlth. Allied Sci. 5, p. 2.

DOI:10.7537/marsnsj150517.11.

FAO (2014): The State of World Fisheries and Aquaculture. Rome, p. 223.

GOWDA, S. K., V. R. B. SASTRY (2000): Neem (Azadirachta indica) seed cake in animal feeding - Scope and Limitations - Review. Asian-Aus. J. Anim. Sci. 13, 720-728.

DOI: 10.5713 /ajas.2000.720

GIRISH, K., B. S. SHANKARA (2008): Neem - A Green Treasure. eJBio. 4, 102-111.

HARIKRISHNAN, R., M. N. RANI, C. BALASUNDARAM (2003): Hematological and biochemical parameters in common carp, Cyprinus carpio, following herbal treatment for Aeromonas hydrophila infection. Aquaculture 221, 41-50.

DOI: 10.1016/S0044-8486(03)00023-1

KABEH, J. D., M. G. D. S. S. JALINGO (2007): Mini review: Exploiting Neem (Azadirachta indica) resources for improving the quality of life in Taraba State, Nigeria. Int. J. Agric. Biol. 3, 530-532.

KWAWUKUME, A. A., K. G. ANING, J. A. AWUNI, H. OTSYINA, B. A. WUMBILA (2013): The effects of Azadirachta indica (Neem) leaf extract on white blood cell count and the immune response of chickens vaccinated with newcastle disease vaccine. Int. J. Curr. Sci. 2013, 7: 23-31.

MADHURI, S., A. K. MANDLOI, G. PANDEY, Y. P. SAHNI (2012): Antimicrobial activity of some medicinal plants against fish pathogens. Int. Res. J. Pharm. 3, 28-30.

MUKESH, K. B., K. J. JITENDER, Y. SATYANARAYANA, A. DEVIVARAPRASADREDDY (2012): Animal and plant originated immunostimulants used in aquaculture. J. Nat. Prod. Plant Resour. 2, 397-400.

NAGALAKSHMI, D., V. R. B. SASTRY, D. K. AGRAWAL, R. C. KATIYAR, S. V. S. VERMA, (1996): Performance of broiler chicks fed on alkali-treated neem (Azadirachta indica) kernel cake as a protein supplement. Br. Poult. Sci. 37, 809-818.

DOI: 10.1080/00071669608417910 
O. E. Ubiogoro et al.: Growth performance and sensory parameters of African catfish (Clarias gariepinus) fed with sublethal dose of neem leaf extracts and its antibacterial effects

NGAMSAENG, A., M. WANAPAT, S. KHAMPA (2006): Evaluation of local tropical plants by in vitro rumen fermentation and their effects on fermentation end-products. Pak. J. Nutr. 5, 414-418.

DOI: $10.3923 /$ pjn.2006.414.418

NIRANJAN, P. S., S. J. UDEYBIR, D. N. VERMA (2008): Mineral and antinutritional factors of common tree leaves. Indian Vet. J. 85, 1067-1069.

NNENNA, O. P., A. O.ANIEBO (2013): Toxicity and nutritional assessment of aqueous Azadirachta indica (neem) leaf extract in broiler chicks. Int. J. Biosci. 3, 172-180.

DOI: 10.12692/ijb/3.6.172-180.

ODUNSI, A. A., S. A. ADEGBILE, T. O. AKANDE, T. B. OLAYENI (2009): Neem (Azadirachta indica) seed cake in the diets of cockerel chickens. Int. J. Poult. Sci. 8, 47-51.

DOI: 10.3923/ijps.2009.47.51

OFORJINDU, O. (2006): The toxicity graded levels of graded levels of Neem (Azadirachta indica) leaves meal. B. Agric. Tech. Thesis, Federal University of Technology, Owerri.

OGBUEWU, I. P. (2008): Physiological response of rabbits fed graded levels of neem (Azadirachta indica) leaf meal. M.Sc Thesis. Federal University of Technology, Owerri.

OGBUEWU, I. P., Y. U. ODOEMENAM, H. O. OBIKAONU, M. N. OPARA, O. O. EMENALOM, M. C. UCHEGBU, I. C. OKOLI, B. O. ESONU, M. U. ILOEJE (2011): The growing importance of neem (Azadirachta indica A. Juss) in agriculture, industry, medicine and environment: A review. Res. J. Med. Plant. 5, 230-245.

DOI: $10.3923 /$ rjmp.2011.230.245

ONIOVOSA, U. E., O. O. AINA, S. A. ALARAPE, O. E. BABALOLA, O. K. ADEYEMO, (2017): Effects of Neem Leaf Aqueous Extract on Organ Histology, Haematological Parameters and Biochemical Indices in Catfish. Alex. J. Vet. Sci. 54, 17-24.

DOI: 10.5455/ajvs.256015.

ORWA, C., A. MUTUA, R. KINDT, R. JAMNADASS, A. SIMONS (2009): Agroforestree Database: a tree reference and selection guide. Version 4.0.

PAENGKOUM, P. (2010): Effect of neem (Azadirachta indica) and leucaena (Leucaena leucocephala) fodders on digestibility, rumen fermentation and nitrogen balance of goats fed corn silage. J. Anim. Vet. Adv. 9, 883-886.

DOI: $10.3923 /$ javaa.2010.883.886

PEDGE, S. S., S. D. AHIRRAO (2012): Antimicrobial activities of turmeric and ginger root used in the treatment of infectious fish disease. IJRBS. 2, 81-84.

RAM, M. S., G. ILVAZHAGAN, S. K. SHARAMA, S. A. DHANRAJ, B. SURESH (2002): Antimicrobial activity of a new vagina contraceptive NIM-76 from neem oil (Azaridacta indica). J. Ethnopharmacol. 71, 377-382.

RAMANA, D. B. V., S. SINGH, K. R. SOLANKI, A. S. NEGI (2000): Nutritive evaluation of some nitrogen and non-nitrogen fixing multipurpose tree species. Anim. Feed Sci. Technol. $88,103-111$.

DOI:10.1016/S0377-8401(00)00200-5

Vet. arhiv 89 (5), 709-721, 2019 
O. E. Ubiogoro et al.: Growth performance and sensory parameters of African catfish (Clarias gariepinus) fed with sublethal dose of neem leaf extracts and its antibacterial effects

RAO, S. B. N., V. RADHIKA, N. SINGH, T. K. DUTTA (2011): Evaluation of mineral adequacy of natural browse species and concentrate ingredients for goats. Livest Res. Rural Dev., 23.

RAVIKUMAR S., A. G. N. ANITHA, S. G. PALANI, A. KALAIARASI (2011): In vitro antibacterial activity of coastal medicinal plants against isolated bacterial fish pathogens. Int. J. Pharma. Res. Dev. 3, 109-116.

SONAIYA, E. B. (1993): Evaluation of non-conventional feed ingredients as supplements for scavenging chicken. Proc. VII World Conf. Anim. Prod., Edmonton, Canada, pp. 28-29.

SHAILENDER, M., C. H. SURESH-BABU, R. S. RAJAGOPAL (2013): Toxic effect of Neem, Azadirachta indica plant bark on growth and survival of freshwater catfish, Pangasius hypophthalmus. Int. J. Toxicol. Appl. Pharmacol. 3, 39-43.

TALPUR, A. D., M. IKHWANUDDIN (2012): Azadirachta indica (neem) leaf dietary effects on the immunity response and disease resistance of Asian seabass, Lates calcarifer challenged with Vibrio harveyi. Shell Fish Immunol. 34, 254-264.

DOI: $10.1016 /$ j.fsi.2012.11.003

TIWARY, M. K., A. PANDEY (2010): Feeding neem (Azadirachta indica) products to small ruminants as anthelmentics. Food Sci. Technol. Lett. 1, 10.

UKO, O. J., T. N. KAMALU (2001): The Neem tree (Azadirachta indica) - Uses, and potentials. Nig. J. Exptal. Applied Biol. 2, 223-229.

UKO, O. J., T. N. KAMALU (2007): Performance and Carcass characteristics of Broilers Fed raw and heat- treated Neem (Azadirachta indica, A. juss) seed kernels. Anim. Prod. Res. Adv. 3, $91-98$.

DOI:10.4314/apra.v3i2.36373

UKO, O. J., T. N. KAMALU (2008): Trend of food consumption and efficiency of broiler production with raw or heat-treated neem kernels. Arch. Zootec. 57, 489-496.

UBIOGORO, O. E., S. A. ALARAPE, A. B. SAKA, O. K. ADEYEMO: Rast i senzorni pokazatelji afričkog soma (Clarias gariepinus) hranjenog subletalnom dozom ekstrakta lišća nima (azadirahte) i njegovi antibakterijski učinci. Vet. arhiv 89, 709-721, 2019.

\section{SAŽETAK}

U ovom su radu istraženi antibakterijski učinci lišća nima, kao i rast i senzorni pokazatelji afričkog soma (Clarias gariepinus) hranjenog ovim lišćem. Upotrijebljeno je 90 odraslih afričkih somova (42,40 $\pm 2,50 \mathrm{~g})$. Pokusna je skupina izložena tijekom dva tjedna 3,5 \% i 7 \% LC50 vodenom ekstraktu lišća nima dodanog u komercijalnu hranu tijekom četiri tjedna, dok je kontrolna skupina hranjena netretiranom hranom. Određena je tjelesna dužina i masa nasumično odabranih riba za provjeru organoleptičkih pokazatelja. Škrge i uzorci 
O. E. Ubiogoro et al.: Growth performance and sensory parameters of African catfish (Clarias gariepinus) fed with sublethal dose of neem leaf extracts and its antibacterial effects

kože prikupljeni su za bakteriološku analizu, dok su uzorci mišića pripremljeni za senzornu analizu. Prosječna konzumacija hrane bila je pod znakovitim utjecajem $(\mathrm{P}<0,05)$ lišća nima, neovisno o koncentraciji, u odnosu na kontrolnu skupinu. Prosječan prirast bio je znakovito viši $(\mathrm{P}<0,05)$ u riba hranjenih lišćem nima u odnosu na kontrolnu skupinu, dok je konverzija hrane bila znakovito niža $(\mathrm{P}<0,05)$ u skupini hranjenoj lišćem nima, neovisno o dozi. Ribe u svim skupinama bile su naizgled zdrave uz 100\%-tno preživljenje. Utvrđen je zamjetan pad brojnosti ukupnih bakterija u škrgama i na koži s porastom koncentracije lišća nima. Bakterije Micrococci spp. i Bacillus subtilis nisu izolirane iz škrga, ali su utvrđene u koži, kao i E. coli i Pseudomonas fluorescens. Nisu utvrđene znakovite razlike senzornih pokazatelja. Dodatak lišća nima ima visok antibakterijski učinak praćen odličnim pokazateljima rasta te općom prihvatljivošću tkiva ribe za konzumaciju.

Ključne riječi: akvakultura; nim; antibakterijski; rast; Clarias gariepinus 
